\title{
New records of Craniophora minuscula Kiss et Jinbo, 2016 (Lepidoptera, Noctuidae, Acronictinae) from Russia
}

\section{Новые находки Craniophora minuscula Kiss et Jinbo, 2016 (Lepidoptera, Noctuidae, Acronictinae) в России}

\author{
Á. Kiss*, A.Yu. Matov** \\ А. Kuсc*, А.Ю. Матов** \\ * Mátra Museum of the Hungarian Natural History Museum, Kossuth u. 40, Gyöngyös H-3200 Hungary.
* Музей Матра Венгерского музея естественной истории, ул. Кошут, 40, Дьёндьёш Н-3200 Венгрия.
**Zoological Institute of Russian Academy of Sciences, Universitetskaya Nab. 1, Sankt-Petersburg 199034 Russia.
**Зоологический институт РАН, Университетская наб. 1, Санкт-Петербург 199034 Pоссия.
}

Keywords: Russian Far East, Japan, genitalia, abdominal segment, external variability.

Ключевые слова: Дальний Восток России, Япония, гениталии, сегменты брюшка, внешняя изменчивость.

Abstract. In the present study, we give new faunistical records of Craniophora minuscula Kiss et Jinbo, 2016 from the Russian Far East and compare the male and female genitalia and the last abdominal segments of the Japanese and Russian Far Eastern populations and with C. pacifica Filipjev, 1927

Резюме. В статье приводятся находки Craniophora minuscula Kiss et Jinbo, 2016 как нового вида для фауны Дальнего Востока России. Показаны различия гениталий самцов и самок из Японии и Дальнего Востока России и отличия от близкого вида C. pacifica Filipjev, 1927.

\section{Introduction}

Craniophora minuscula Kiss et Jinbo, 2016 was described as a member of Craniophora s. str. [Kiss, 2017] from Japan. This species, based on the original description [Kiss, Jinbo, 2016], was considered as endemic to Japan, where it occurs in three well separated populations. The first population lives in Hokkaido, where the species is widely distributed [Sugi, 1982]; the other two occurs in two rather distant areas of Honshu: Sodeyama, Iwate Prefecture [Saito, 1981], Togakushiyama, Nagano Prefecture [Sugiyama, 1989; Tanaka, Umetsu, 1994] and Hiroshima and Okayama Prefectures [Uno, 1986]. However, recently the first author found some $C$. pacifica-like specimens from the Russian Far East in the collection of Zoological Institute of the Russian Academy of Sciences (Saint-Petersburg, Russia) and the private collections of Péter Gyulai (Miskolc, Hungary) which were proved to belong to $C$. minuscula (Kiss, 2017). The determination of the specimens in the collection of Zoological Institute of the Russian Academy of Sciences was checked by the study of the genitalia by the second author.

Present paper contains the data of these additional specimens and the comparisons of the male and female genitalia and the last abdominal segments of the Japa- nese and Russian Far Eastern populations and with C. pacifica Filipjev, 1927.

\section{Material and methods}

The examined and illustrated specimens are preserved in the collections of Hungarian Natural History Museum (HNHM, Hungary, Budapest), National Museum of Nature and Science (NSMT, Japan, Tsukuba), Staatliches Museum für Naturkunde Karlsruhe (SMNK, Germany, Karlsruhe), Tomakomai Experimental Forest Station of Hokkaido University (TOEF, Japan, Tomakomai), Zoological Institute of the Russian Academy of Sciences (ZISP, Russia, Saint-Petersburg) and the private collections of Péter Gyulai (Pgy, Hungary, Miskolc) and Seiji Miyake (SMC, Japan, Okayama).

The habitus pictures of the adults were taken with Canon EOS 550D with Tamron AF 90mm F2.8 Di Macro 1:1 SP and Leica DFC290. The genital dissections were made by the authors and were based on the technique described in Kiss and Jinbo, 2016, except a few genitalia preparates in the collection of ZISP which are preserved in small plastic tubes with glycerine. The photos of the slides were taken by an Olympus DP70 digital microscope camera connected with an Olympus SZX12 zoom stereo microscope and Leica MZ95 microscope.

\section{Taxonomic part}

Craniophora minuscula Kiss et Jinbo, 2016 Figs 1-6, 9-12, 15-18, 21-24, 27-30.

Craniophora minuscula Kiss et Jinbo, 2016, Journal of AsiaPacific Entomology, 19: 930, figs 1, 2, 8, 9, 15, 16, 27, 33.

= Craniophora pacifica Sugi, 1982, Moths of Japan 1: 681, 2: 347 , pl. 197: figs 18, 19, nec Filipjev [1927].

=Craniophora pacifica Eda et Yanagita, 2011, The Standard of Moths in Japan 2: 302, pl. 2-072: figs 22, 23, nec Filipjev [1927]. 
1
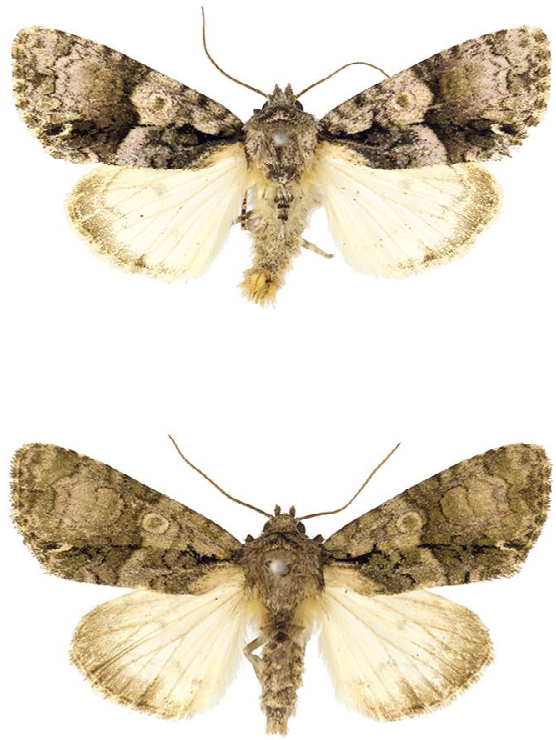

3
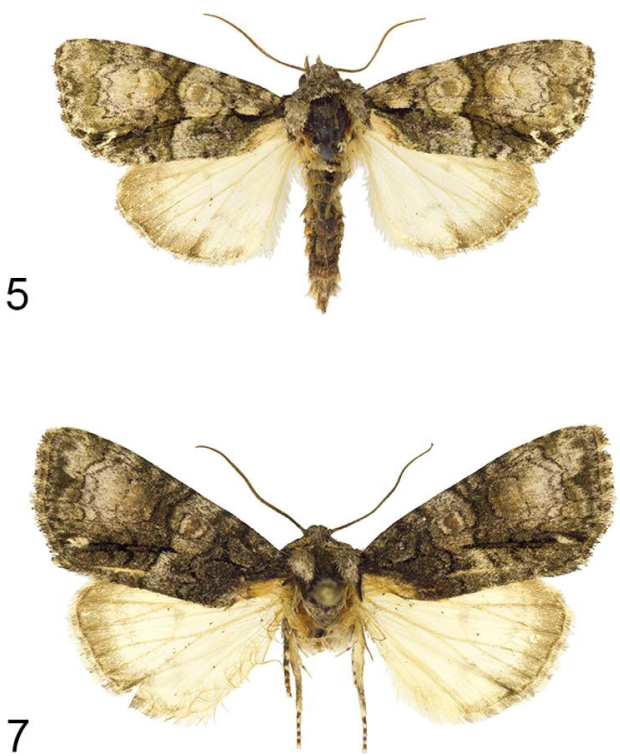

2

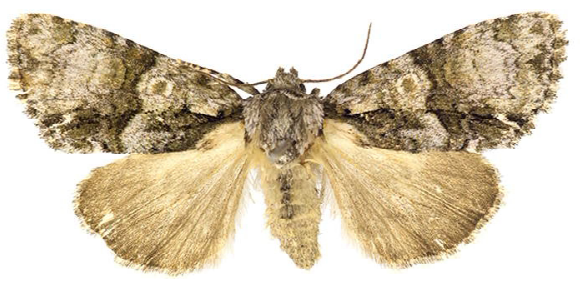

4

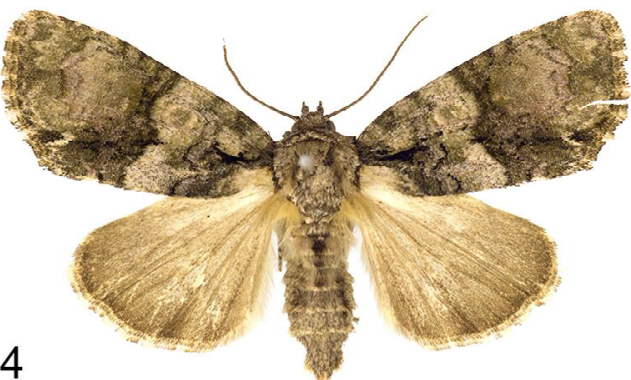

6

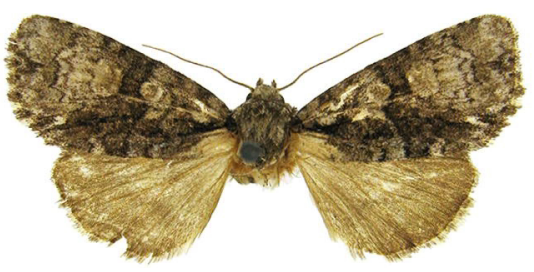

8

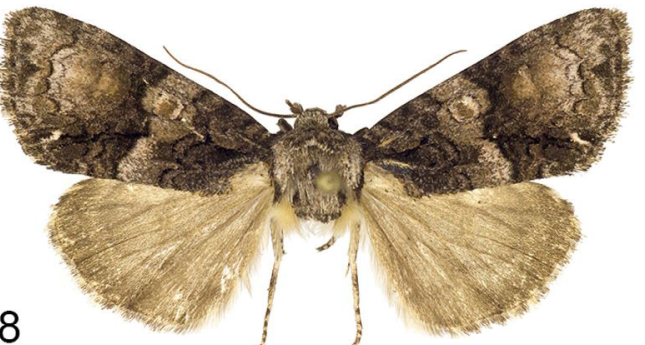

Figs 1-8. Craniophora minuscula and C. pacifica adults: 1 - C. minuscula, male, Holotype, Japan, Hokkaido, slide No.: KA1174m (coll. TOEF), 2 - C. minuscula, female, Paratype, Japan, Hokkaido, slide No.: KA1176f (coll. TOEF), $3-$ C. minuscula, male, Paratype, Japan, Honshu, Okayama Pref., slide No.: KA1177m (coll. SMC), 4 - C. minuscula, female, Paratype, Japan, Honshu, Okayama Pref., slide No: KA1178f (coll. SMC), 5 - C. minuscula, male, Russia, Primorsky Krai, slide No.: KA1747m (coll. PGy), 6- C. minuscula, female, Russia, Primorsky Krai, slide No.: Matov0499 (coll. ZISP), 7 - C. pacifica, male, Russia, Primorsky Krai, slide No.: KA826m (coll. HNHM), 8- C. pacifica, female, China, Prov. Liaoning, slide No: KA1048f (coll. HNHM). Scale bar $10 \mathrm{~mm}$.

Рис. 1-8. Внешний вид Craniophora minuscula и C. pacifica: 1 - C. minuscula, самец, голотип, Япония, Хоккайдо, KA1174m (coll. TOEF), 2 - C. minuscula, самка, паратип, Япония, Хоккайдо, KA1176f (coll. TOEF), 3 - C. minuscula, caмец, паратип, Япония, Хонсю, Окаяма преф., KA1177m (coll. SMC), 4 - C. minuscula, самка, паратип, Япония, Хонсю, Окаяма преф., KA1178f (coll. SMC), 5 - C. minuscula, самеџ, Россия, Приморский край, KA1747m (coll. PGy), 6 - C. minuscula, самка, Россия, Приморский край, Matov0499 (coll. ZISP), 7 - C. расіfica, самец, Россия, Приморский край, KA826m (coll. HNHM), 8 - C. pacifica, самка, Китай, Аяонин пров., KA1048f (coll. HNHM). Масштаб 10 мм. 
9

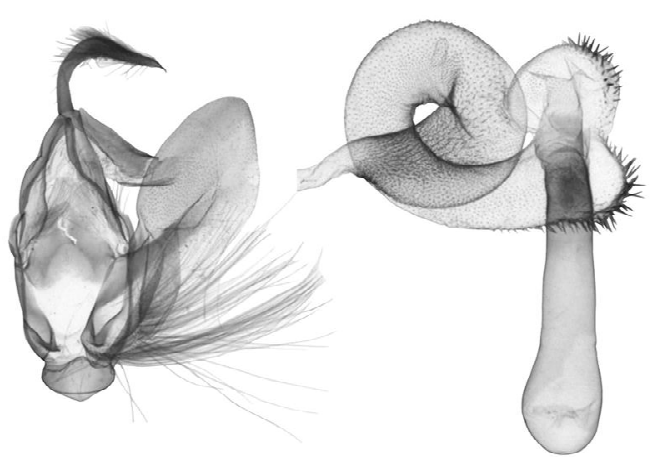

"

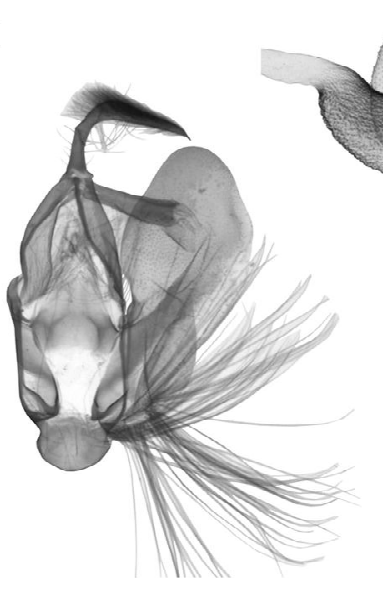

13

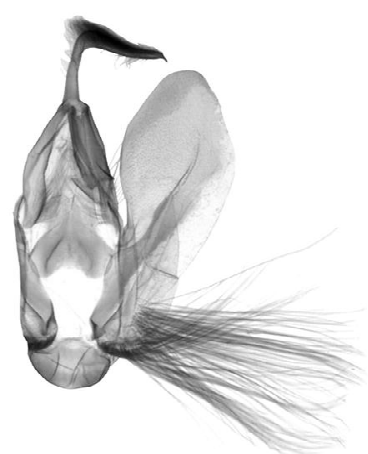

10

12
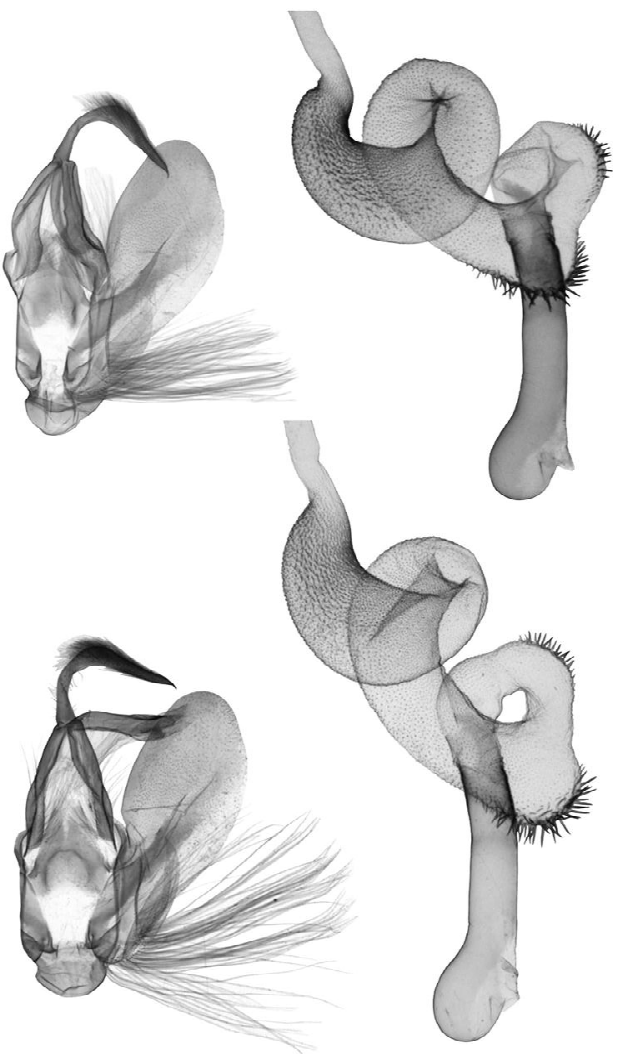

14

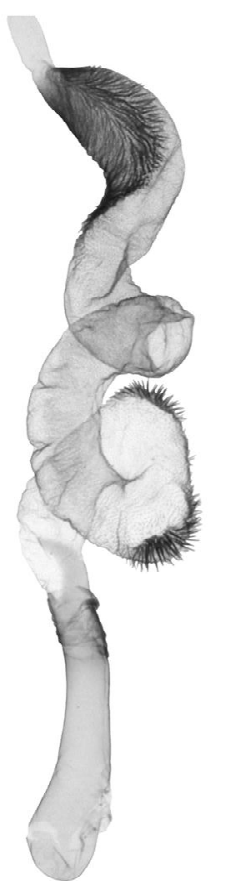

Figs 9-14. Craniophora minuscula and C. pacifica male genitalia: 9 - C. minuscula, Holotype, Japan, Hokkaido, slide No.: KA1174m (coll. TOEF), 10 - C. minuscula, Paratype, Japan, Hokkaido, slide No.: KA944m (coll. NSMT), 11 - C. minuscula, Paratype, Japan, Honshu, Okayama Pref., slide No.: KA1177m (coll. SMC), 12 - C. minuscula, Russia, Primorsky Krai, slide No.: KA1747m (coll. PGy), 13 - C. pacifica, Russia, Primorsky Krai, slide No.: KA826m (coll. HNHM), $14-$ C. pacifica, Russia, Primorsky Krai, slide No.: KA1020m (coll. SMNK). Scale bar $1 \mathrm{~mm}$.

Рис. 9-14. Гениталии самџов Craniophora minuscula and C. pacifica: 9 - C. minuscula, голотип, Япония, Хоккайдо, слайд № KA1174m (coll. TOEF), 10 - C. minuscula, паратип, Япония, Хоккайдо, слайд № KA944m (coll. NSMT), 11 - C. minuscula, паратип, Япония, Хонсю, Окаяма преф., KA1177m (coll. SMC), 12 - C. minuscula, Россия, Приморский край, KA1747m (coll. PGy), 13 - C. pacifica, Россия, Приморский край, слайА № KA826m (coll. HNHM), 14 - C. pacifica, Россия, Приморский край, слайА № KA1020m (coll. SMNK). Масшта6 1 мм. 
15

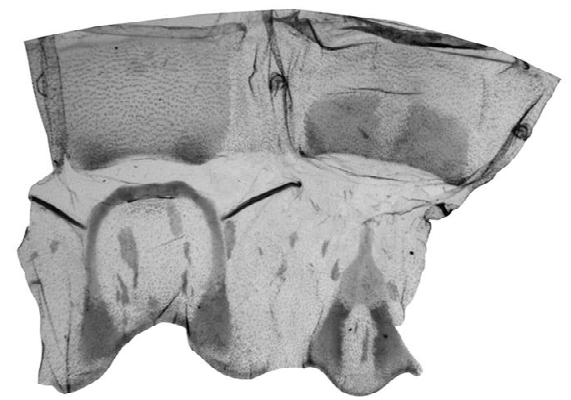

17

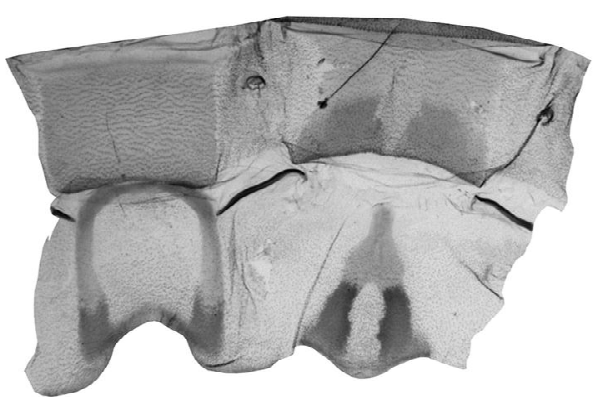

19

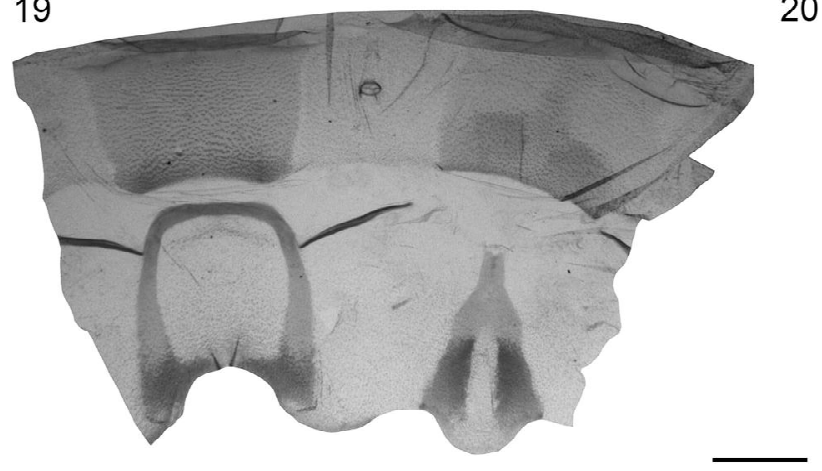

16

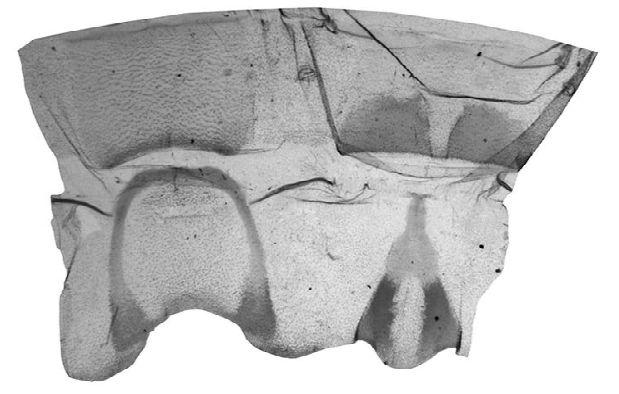

18

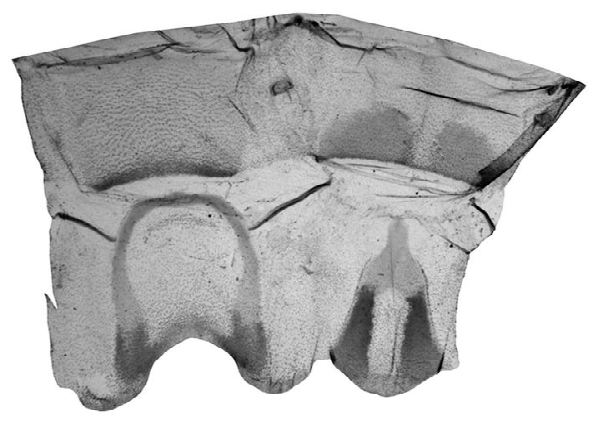

20

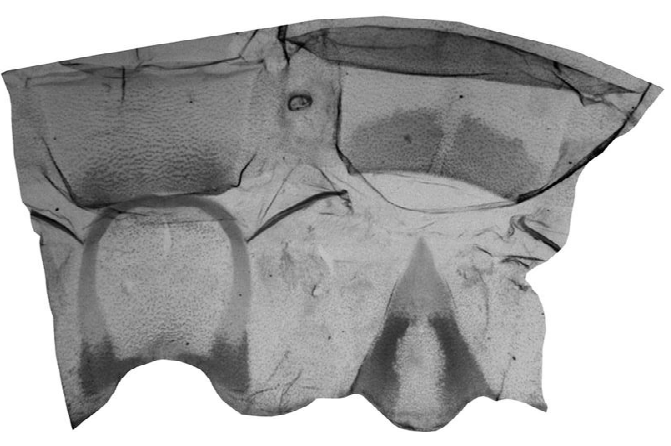

Figs 15-20. Craniophora minuscula and C. pacifica male $7^{\text {th }}$ and $8^{\text {th }}$ abdominal segments: $15-$ C. minuscula, Holotype, Japan, Hokkaido, slide No:: KA1174m (coll. TOEF), 16 - C. minuscula, Paratype, Japan, Hokkaido, slide No.: KA944m (coll. NSMT), 17 - C. minuscula, Paratype, Japan, Honshu, Okayama Pref., slide No.: KA1177m (coll. SMC), 18 - C. minuscula, Russia, Primorsky Krai, slide No.: KA1747m (coll. Pgy), 19 - C. pacifica, Russia, Primorsky Krai, slide No.: KA826m (coll. HNHM), 20 - C. pacifica, Russia, Primorsky Krai, slide No.: KA1020m (coll. SMNK). Scale bar $1 \mathrm{~mm}$.

Рис. 15-20. 7-й и 8-й сегменты брюшка самџов Craniophora minuscula и C. pacifica: 15 - C. minuscula, голотип, Япония, ХоккайАо, слайА № KA1174m (coll. TOEF), 16 - С. minuscula, паратип, Япония, Хоккайло, слайА № KA944m (coll. NSMT), 17 - C. minuscula, паратип, Япония, Хонсю, Окаяма преф., скайА № KA1177m (coll. SMC), 18 - C. minuscula, Россия, Приморский край, слайА № KA1747m (coll. Pgy), 19 - C. расіfica, Россия, Приморский край, слайА № KA826m (coll. HNHM), 20 - C. pacifica, Россия, Приморский край, слайА № KA1020m (coll. SMNK). Масштаб 1 мм.

Material. Holotype: $10^{7}-$ Japan, Hokkaido: Mukawa Town, Hobetsu, Fukuyama, 22.06.1997; slide No.: KA1174m (coll. TOEF) ; $10^{7}$, Paratype, Rikubetsu Town, Kunbetsu, 30.05.1998, leg. H. Kogi; slide No.: KA1172m (coll. TOEF); 10', Paratype, Hamanaka Town, Kiritappu, 0.08.1989; slide No.: KA1173m (coll. TOEF); 1 क, Paratype, Nemuro City, Konbumori, 3.08.1989; slide No.: KA1175f (coll. TOEF); 10', 1우, Paratype, Kushiro, Shibecha, Fututsuyama, 12.08.1978, leg. K. Ijima; slide No.: KA946f (coll. NSMT); 2.08.1989, leg. K. Ijima; slide No.: KA1176f (coll. TOEF); 10², Paratype, Gojikkoku, Shibecha, 1.08.1978, leg. Y. Kishida (coll. NSMT); 10', Paratype, Nokanan, Ashibetsu, 15.08.1993, leg. H. Kobayashi (coll. NSMT); 5우, Paratype, Ashibetsu, 15.08.1993, leg. M. Owada; slide Nos. KA942m, KA943m, KA944m (coll. NSMT); $10^{7}, 1$, , Paratype, Sharigun, Koshimizucho, 30.07.1978, leg. Y. Kishida; slide No.: KA945m (coll. NSMT); HONSHU: 10 , 1, Paratype, Okayama, Takahasi, Iwayakei, alt. $230 \mathrm{~m}, 30.05 .2009$; slide No.: KA1177m (coll. SMC); 13.06.2009; slide No.: KA1178f (coll. SMC). Russia, Primorsky Krai: 20', Anisimovka, 23.08.1980, leg. A. Nekrasov (preparate in glycerine, coll. ZISP); 20-21.07.2012, leg. L. Krasilnikov (preparate in glycerine, coll. ZISP); 107, Barabash, 17.08.1985, leg. M. Danilevskij (preparate in glycerine, coll. ZISP); $10^{7}, 1$, Kedrovaja Pad, 15-18.08.1966, leg. A. Lisetskij, slide No.: Matov0499 (coll. ZISP); 26.07.1996, leg. V. Kononenko (preparate in glycerine, coll. ZISP); 1엉 Slavjanka, 13- 
21

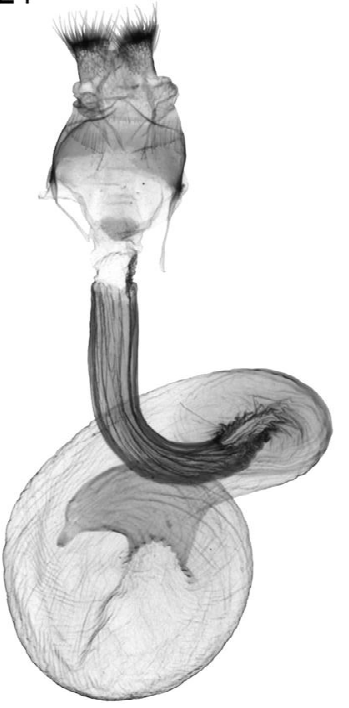

22

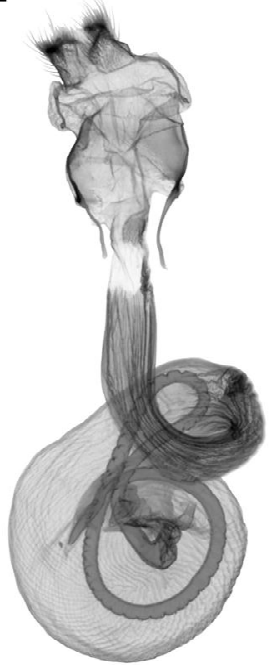

23

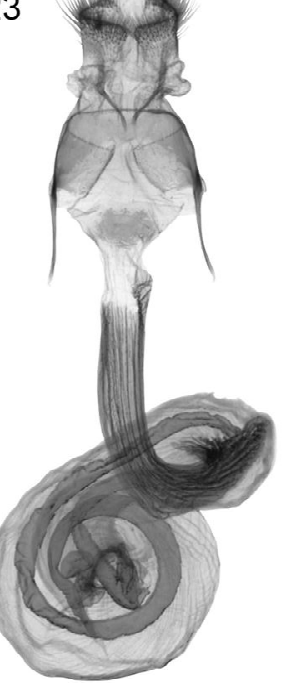

24

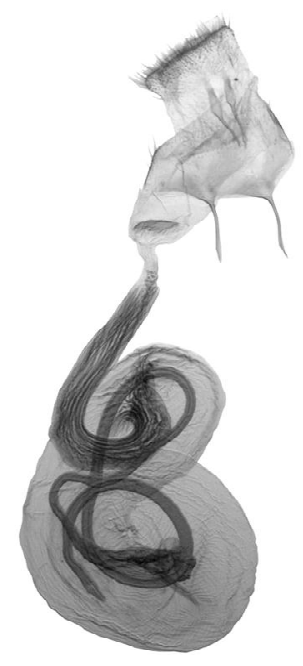

25

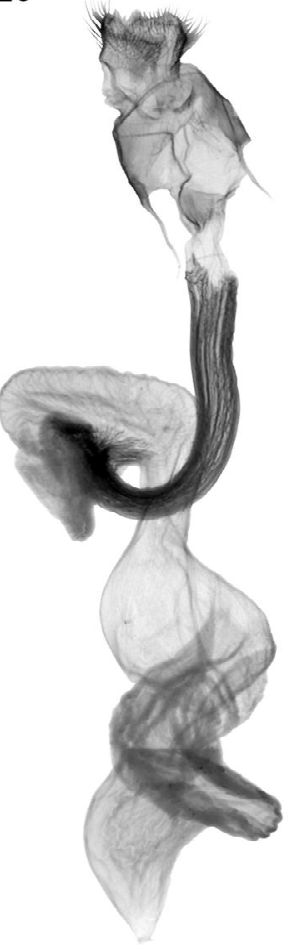

26

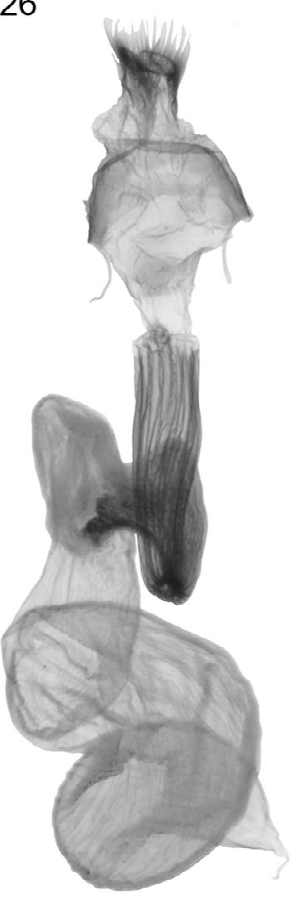

Figs 21-26. Craniophora minuscula and C. pacitica temale genitalia: 21 - C. minuscula, Paratype, Japan, Hokkaido, slide No.: KA946f (coll. NSMT), 22 - C. minuscula, Paratype, Japan, Hokkaido, slide No.: KA1176f (coll. TOEF), 23 - C. minuscula, Paratype, Japan, Honshu, Okayama Pref., slide No.: KA1178f (coll. SMC), 24 - C. minuscula, Russia, Primorsky Krai, slide No.: Matov0499 (coll. ZISP), 25 - C. pacifica, Russia, Primorsky Krai, slide No.: KA504f (coll. HNHM), 26 - C. pacifica, China, Prov. Liaoning, slide No.: KA1048f (coll. HNHM). Scale bar $1 \mathrm{~mm}$.

Рис. 21-26. Гениталии самок Craniophora minuscula и C. pacifica: 21 - C. minuscula, паратип, Япония, Хоккайдо, КА946f (coll. NSMT), 22 - C. minuscula, паратип, Япония, Хоккайдо, KA1176f (coll. TOEF), 23 - C. minuscula, паратип, Япония, Хонсю, Окаяма преф., KA1178f (coll. SMC), 24 - C. minuscula, Россия, Приморский край, Matov0499 (coll. ZISP), 25 - C. pacifica, Россия, Приморский край, KA504f (coll. HNHM), 26 - C. pacifica, Китай, Аяонин пров., KA1048f (coll. HNHM). Масштаб $1 \mathrm{MM}$. 
27

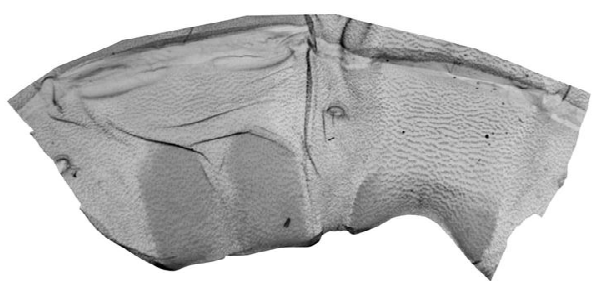

29

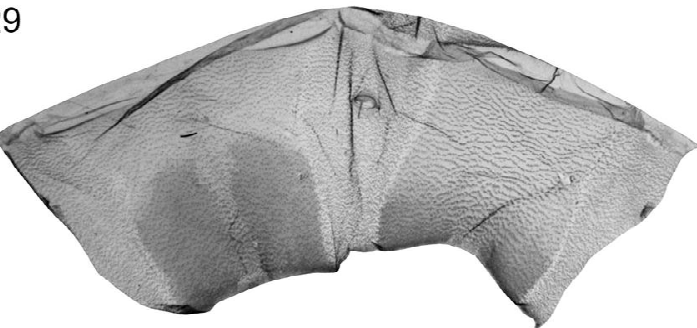

31

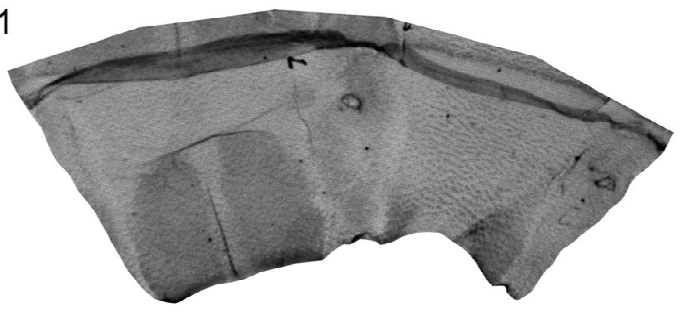

28

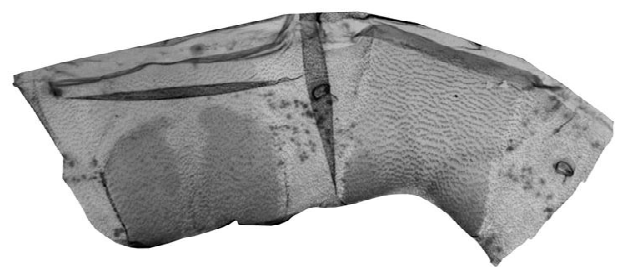

30

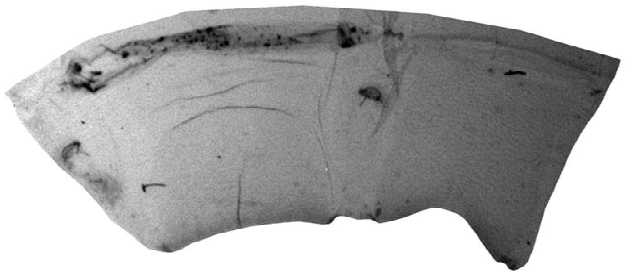

32

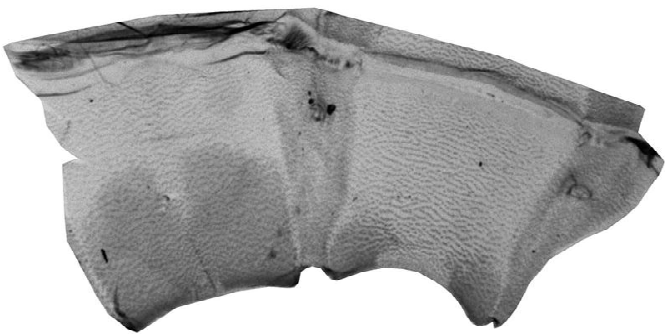

Figs 27-32. Craniophora minuscula and C. pacifica female $7^{\text {th }}$ abdominal segments: $27-$ C. minuscula, Paratype, Japan, Hokkaido, slide No.: KA1175f (coll. TOEF), 28 - C. minuscula, Paratype, Japan, Hokkaido, slide No.: KA1176f (coll. TOEF), 29 C. minuscula, Paratype, Japan, Honshu, Okayama Pref., slide No.: KA1178f (coll. SMC). 30 - C. minuscula, Russia, Primorsky Krai, slide No.: Matov0499 (coll. ZISP), 31 - C. pacifica, Russia, Primorsky Krai, slide No.: KA504f (coll. HNHM), 32 - C. pacifica, China, Prov. Liaoning, slide No.: KA1048f (coll. HNHM). Scale bar $1 \mathrm{~mm}$.

Рис. 27-32. 7-й сегмент брюшка самок Craniophora minuscula и C. pacifica: 27 - C. miпuscula, паратип, Япония, Хоккайдо, KA1175f (coll. TOEF), 28 - C. minuscula, паратип, Япония, Хоккайдо, KA1176f (coll. TOEF), $29-$ C. minuscula, паратип, Япония, Хонсю, Окаяма преф., KA1178f (coll. SMC). 30 - C. minuscula, Россия, Приморский край, Matov0499 (coll. ZISP), 31 - C. pacifica, Россия, Приморский край, KA504f (coll. HNHM), 32 - С. расifica, Китай, Аяонин пров., КА1048f (coll. HNHM). Масштаб 1 мм.

25.08.1995. leg. A. Danchenko (preparate in glycerine, coll. ZISP); 10", Zanadvorovka village, 12-18.08.1991, leg. Berg, slide No.: KA1747m (coll. PGy).

Diagnosis. Craniophora minuscula (figs 1-6) externally resembles $C$. pacifica (figs 7,8 ) by its average smaller size; the typical specimens by much ligher ground colour of forewing and slightly stronger rosy-tint brilliance (the somewhat greenish ground coloured darker form also with rosy-tint brilliance); by the hook-like white dash next to the $\mathrm{Cu} 2$ vein; in males, by the whitish hindwing with evenly narrowing, brownish marginal band reaching the tornal angle and indistinct discal line. In the male genitalia (figs 9-12), C. minuscula can be distinguished from $C$. pacifica (figs 13,14 ) by the smaller size of the clasping apparatus, by the more rounded shape of the valvae, by basally and terminally coiled vesica with numerous small, spinulose structures on its surface in two patches. In the male last abdominal segments (figs 15-
$18)$, the $8^{\text {th }}$ tergite more triangular, with more or less regular, oval "window"; the two lateral sections of the $8^{\text {th }}$ sternite gradually more widening than in C. pacifica (figs. 19, 20). In the female genitalia (figs 21-24), ductus bursae shorter, appendix-corpus bursae complex rather simpler, tubular and recurved with a distal loop than in C. pacifica (figs 25, 26). In the female last abdominal segments (figs 27-30), C. minuscula differs from C. pacifica (figs 31,32 ) by its average smaller size, the slightly more quadrangular $7^{\text {th }}$ sternite (not widening at the proximal edge than in C. pacifica) with narrower and shallower "window" distally.

Distribution. Japan (Hokkaido, Honshu) and Russian Far East (Primorsky Krai).

Remarks. The southernmost populations from Hiroshima and Okayama Prefectures (figs 3,4) externally differ from the Hokkaido, northern Honshu (figs 1, 2) and the Russian Far Eastern (figs 5,6) populations by their more uniform and 
much darker ground colour of forewing with some greenish shade and on average somewhat larger size. The Russian Far Eastern population is more greyish-brownish than the two northern Japanese populations living in Hokkaido and northern Honshu, lacking the rosy-tint brilliance which is typical of the Japanese specimens.

In the genitalia, both of male (figs 9-12) and female (figs 21-24) genitalia do not show any differential characters among the three population groups. In the last abdominal segments of the male (figs 15-18), the three population groups have some minor differences. In the females, the last abdominal segments of the populations occurring in Hiroshima and Okayama Prefectures (fig. 29) have larger abdominal segments, coincide with its larger size comparing to the other specimens (figs 27, 28, 30). However, solely these slight differences do not support the separation of these populations as a distinct subspecies.

The external similarity of the Russian Far Eastern and the Hokkaido population is probably coincided with the same latitude, while the difference of the Hiroshima and Okayama Prefectures populations is probably originated from the different host plant usage [Kiss, Jinbo, 2016].

\section{Acknowledgements}

We would like to thank to László Ronkay (HNHM), Zoltán Varga (University of Debrecen, Hungary) and Vladimir Dubatolov (Institute of Systematics and Ecology of Animals, Russia) for checking the manuscript. The first author was funded in part by the TÁMOP-4.2.2B-15/1/KONV2015-0001 project. The project has been supported by the European Union, co-financed by the European Social Fund. The study of the second author was performed in the frames of the state research project AAAA-A17-117030310210-3 and supported by the Russian Foundation for Basic Research (grant No 17-04-00754).

\section{References}

Eda E., Yanagita Y. 2011. Acronictinae // Kishida Y. (Ed.). The Standard of Moths in Japan. Vol.2. Tokyo: Gakken Education Publishing. P.295-303. P1.2070-2073. [In Japanese].

Filipjev N. 1927. Zur Kenntniss der Heteroceren (Lepidopteren) von Sutshan (Ussuri Gebiet) // Annuaire du Musee Zoologique de l'Academie des Sciences d'l'URSS. Vol.28. P.219-264.

Kiss Á. 2017. Taxonomic review of the Craniophora s.1. (Lepidoptera, Noctuidae, Acronictinae) generic complex with description of 8 new genera and 13 new species // Zootaxa. No.4355(1). P.1-90.

Kiss Á., Jinbo U. 2016. Craniophora minuscula sp.n., a new species of the genus Craniophora Snellen, 1867 (Lepidoptera: Noctuidae: Acronictinae) from Japan // Journal of AsiaPacific Entomology. Vol.19. P.929-935.

Saito O. 1981 [Kitakami sanchi, sodeyama ni sansuru ga sûshu no saishû kiroku.] // The Transaction of the Iwate Entomological Society. Vol.7. P.15-16. [In Japanese].

Sasaki A. 1999. Larva and host plant of Craniophora pacifica Filipjev (Noctuidae) // Japan Heterocerists' Journal. Vol.202. P.17-18. [In Japanese].

Sugi S. 1982. Acronictinae // Inoue H., Sugi S., Kuroko H., Moriuti S., Kawabe A., Owada M. (Eds.). Moths of Japan. Vol.1. Tokyo: Kodansha. P.671-682. Vol.2. Tokyo: Kodansha. P.345-347. Pl.165-167, 358-359. [In Japanese].

Sugiyama T. 1989. [Togakushi kôgen de kushirotsumajirokenmon wo saishû] // Yugato. Vol.115. P.17. [In Japanese].

Tanaka M., Umetsu K. 1994. On some moths collected at Togakushiyama, Nagano Prefecture // Japan Heterocerists' Journal. Vol.180. P.65-67. [In Japanese].

Uno H. 1986. Notes on the distribution of Craniophora pacifica Filipjev (Noctuidae) in Honshu // Japan Heterocerists' Journal. Vol.136. P.171. [In Japanese]. 